Int. J. Electrochem. Sci., 11 (2016) 5009 - 5020

International Journal of

ELECTROCHEMICAL

SCIENCE

www.electrochemsci.org

\title{
Electrochemical Degradation of Diethyl Phthalate under Different Operating Conditions
}

\author{
Cheng-Di Dong ${ }^{1}$, Te-San Chen ${ }^{1}$, Chiu-Wen Chen ${ }^{1}$, Kuo-Lin Huang ${ }^{2, *}$ \\ ${ }^{1}$ Department of Marine Environmental Engineering, National Kaohsiung Marine University, \\ Kaohsiung 81157, Taiwan (ROC) \\ ${ }^{2}$ Department of Environmental Science and Engineering, National Pingtung University of Science and \\ Technology, Pingtung 91201, Taiwan (ROC) \\ E-mail: huangkl@mail.npust.edu.tw
}

doi: $10.20964 / 2016.06 .77$

Received: 24 March 2016 / Accepted: 28 April 2016 / Published: 4 May 2016

\begin{abstract}
In this study, different operating conditions were tested for the electro-degradation of diethyl phthalate (DEP) (an emerging contaminant) in aqueous solutions. The results show that the DEP electrodegradation followed pseudo first-order kinetics. The degradation efficiencies and (apparent) rate constants of DEP increased with the increase of current density and solution temperature (activation energy $=8.0 \mathrm{~kJ} / \mathrm{mol}$ ), but decreased with initial DEP concentration. The boron-doped diamond (BDD) anode was significantly better than $\mathrm{PbO}_{2}$ and $\mathrm{Pt}$ for DEP degradation and TOC removal. The apparent rate constants were $2.87 \times 10^{-4}, 2.00 \times 10^{-4}$, and $5.00 \times 10^{-5} \mathrm{~s}^{-1}$ for the degradation of $50 \mathrm{mg} / \mathrm{L}$ DEP at 200 $\mathrm{mA} / \mathrm{cm}^{2}$ and $25^{\circ} \mathrm{C}$ in $0.1 \mathrm{M} \mathrm{Na}_{2} \mathrm{SO}_{4}$ solution at $\mathrm{BDD}, \mathrm{PbO}_{2}$, and $\mathrm{Pt}$ anodes, respectively. After $210 \mathrm{~min}$ electrolysis, the BDD achieved total mineralization of $50 \mathrm{mg} / \mathrm{L} \mathrm{DEP}$ in both $0.1 \mathrm{M} \mathrm{Na}_{2} \mathrm{SO}_{4}$ solution and municipal wastewater treatment plant secondary effluent. Hence, the electrochemical method was a promising process for the effective treatment of DEP and similar pollutants in municipal wastewater.
\end{abstract}

Keywords: electrochemical degradation; diethyl phthalate; boron-doped diamond (BDD) electrode; mineralization

\section{$\underline{\text { FULL TEXT }}$}

(C) 2016 The Authors. Published by ESG (www.electrochemsci.org). This article is an open access article distributed under the terms and conditions of the Creative Commons Attribution license (http://creativecommons.org/licenses/by/4.0/). 